\title{
ПОЛУЧЕНИЕ ЭКСТРАКТА ИЗ ВТОРИЧНОГО ВИНОГРАДНОГО СЫРЬЯ
}

\author{
(C) И.А. Кустова ${ }^{*}$ Н.В. Макарова, А.М. Гудкова \\ Самарский государственный технический университет, \\ ул. Молодогвардейская, 244, Самара, 443100 (Россия), e-mail: batkova_ira7@mail.ru
}

Проблема ухудшения окружающей среды, воздействие на организм внешних неблагоприятных факторов приводит к накоплению в организме свободных радикалов, продуктов неполного восстановления кислорода, избыток которых ведет к перекисному окислению липидов и, как следствие, к нарушению функции клеточных мембран. В результате этого возникают многочисленные заболевания. Поэтому важным направлением в пищевой промышленности становится производство продуктов питания с повышенным содержанием биологически активных веществ. Были рассмотрены вопросы влияния используемых технологических параметров на свойства экстракта: химический состав, антирадикальную, антиокислительную активности, восстанавливающую силу. Описаны результаты подбора наиболее оптимальной температуры сушки вторичного виноградного сырья, оптимального растворителя, оптимальной температуры экстракции, продолжительности и самого процесса экстракции. В данной работе используются различные методы определения уровня антиоксидантной активности: содержание общего количества фенольных соединений эквивалент галловой кислоты, флавоноидов и танинов эквивалент катехина, антоцианов эквивалент цианидин-3-гликозида, антирадикальную способность с использованием свободного радикала DPPH (2,2-дифенил-1-пикрилгидразила) мг/мл, антиоксидантную активность по методу ABTS (2,2'-азино-бис(3-этилбензтиазолино-6-сульфоновая кислота) $\mu$ моль тролокса, восстанавливающую силу по методу FRAP с 2,4,6-трипиридил-5-триазином, антиокислительную активность в системе линолевой кислотой. В результате работы выявлено, что при разработке технологии экстракта из вторичного виноградного сырья наиболее значительно на полифенольные и антиоксидантные показатели влияют стадии сушки сырья, кроме этого, сушка позволяет увеличить сроки хранения вторичного сырья, минимизировать отходы предприятия, а также повысить содержание фенольных веществ и флавоноидов. Показано, что использование определенных температур сушки исходного сырья, продолжительности и температуры экстракции, использование смеси этиловый спирт - вода, концентрирование под вакуумом приводят к получению экстрактов выжимок винограда с повышенными антиоксидантными показателями.

Ключевые слова: экстракты, выжимки винограда, антиоксидантная активность, восстанавливающая сила, фенолы, танины, флавоноиды.

Работа выполнена в рамках базовой части государственного задания №2014/199 ФГБОУ ВО «Самарский государственный технический университет» по проекту “Создание научной методологии разработки рещептур и технологий пищевых продуктов для борьбы с оксидативным стрессом в организме человека» код 974.

\section{Введение}

Интерес к экстракту виноградных семян и выжимок продолжает расти на протяжении последних лет. Осведомленность потребителей о потенциальной пользе виноградного экстракта для здоровья увеличивается наряду с растущим количеством исследований воздействия антиоксидантов на организм.

Переработка винограда в соковом и винодельческом производстве является далеко не полным спектром использования виноградной ягоды. В реальных условиях производства не исключены варианты недо-

Кустова Ирина Андреевна - кандидат технических наук, старший преподаватель, e-mail: batkova_ira7@mail.ru Макарова Надежда Викторовна - заведующая кафедрой «ТиООП», доктор химических наук, профессор, e-mail samara.pitanie@gmail.com

Гудкова Анастасия Михайловна - студентка, e-mail:kafedra-pitanie@rambler.ru использования отходов, что приводит к потерям высокоценных веществ, содержащихся в винограде. При производстве винопродукции образуются побочные продукты, которые расцениваются как вторичные материальные ресурсы. Чаще всего они либо поступают на корм скоту, либо вообще вы-

\footnotetext{
* Автор, с которым следует вести переписку.
} 
брасываются [1]. Богатый химический состав винограда (белки, витамины, фруктовые кислоты, микрои макроэлементы) дает огромный потенциал для использования вторичных продуктов винопроизводства и виноматериалов при разработке рецептур снековых продуктов с добавлением экстракта функционального назначения. Повышение эффективности промышленного производства на современном этапе возможно лишь по пути интенсификации и повышения выхода продукции с единицы сырья. Это предполагает наиболее эффективное использование вторичных сырьевых ресурсов при их переработке. В реальных условиях винодельческого производства не исключены варианты недоиспользования отходов, что приводит к потерям высокоценных веществ. Поэтому одной из задач нашей работы является производство экстракта с высокой антиоксидантной активностью из отходов винодельческого предприятия с целью их минимизации. Экстракты из отходов переработки винограда и производства вина приобретают все большую популярность в качестве антиокислителей в липидосодержащих системах: в мясе [2], франкфуртских сосисках [3], говяжьей колбасе [4], спинном жире свинины [5], куриных грудках [6].

Основное количество выжимок и косточек образуется в период сбора винограда и переработки на вино. Такое количество быстропортящихся отходов нельзя сохранить без дополнительной обработки.

Одной из основных стадий получения экстрактов винограда является сам процесс экстракции. От правильного подбора параметров экстракции зависят химический состав и антиоксидантная активность экстрактов [7].

Таким образом, целью работы является разработка технологии экстракта из вторичного виноградного сырья с повышенными антиоксидантными свойствами.

\section{Экспериментальная часть}

Объектами исследования являются мякоть и кожица, косточки, выжимки сортосмеси винограда сортов Мерло, Левокумский и Регент. Для разработки технологии получения биологически активных экстрактов с повышенными антиоксидантными свойствами важное влияние на процесс экстракции оказывают такие параметры, как сушка сырья, подбор растворителя, температура экстракции, продолжительность экстракции. Для анализируемых объектов определен химический состав (общее содержание фенолов, мг галловой кислоты/100 г исходного сырья (ФВ мг ГК/100 г ИС), флавоноидов, мГ катехина/100 г исходного сырья (Фл мГ К/100 г ИС), антоцианов мг цианидин-3-гликозида /100 г исходного сырья (Ац мг ЦГ/100 г ИС), танинов, мг катехина/100 г исходного сырья (Т мг К/100 г ИС)) [8-11] и уровень антиоксидантной активности (способности улавливать свободные радикалы DPPH (2,2'-дифенил-1-пикрилгидразила) [12], ABTS (2,2'-азино-бис(3этилбензтиазолино-6-сульфоновая кислота)) [13], восстанавливающей силы по методу FRAP с 2,4,6трипиридил-5-триазином, способности ингибировать окисление на модели с линолевой кислотой $[14,15]$.

Опыты проводили в трехкратной повторяемости. Статистическую обработку данных анализа осуществляли с помощью программы MS Excel 2007.

\section{Результаты и их обсуждение}

Результаты исследования общего содержания фенольных веществ, общего содержания флавоноидов, танинов и антоцианов вторичного сырья винодельческой промышленности после определенных стадий конвективной сушки при 50-52, 100-102, 130-132 ${ }^{\circ} \mathrm{C}$ и сублимационной сушки (СС) представлены в таблице 1.

Массовая доля влаги вторичного виноградного сырья до тепловой обработки составляет $62 \pm 0,5 \%$. Массовая доля влаги высушенного сырья - не более $14 \pm 0,1 \%$.

Изучая полученные данные таблицы 1 , можно сделать вывод, что тепловая обработка в значительной степени влияет на химический состав и антиоксидантные показатели вторичного виноградного сырья. Заметно увеличиваются показатели общего содержания фенольных веществ, флавоноидов, танинов, а также антиоксидантной активности и восстанавливающей силы. Это может быть связано с тем, что высокая температура, воздействуя на растительные клетки, разрушает их и тем самым облегчает экстракцию общего содержания фенольных веществ. Кроме того, фенольные вещества содержатся в растительных объектах в связанном с сахарами состоянии в виде гликозидов, при взаимодействии высокой температуры связи разрушаются, и фенольные вещества высвобождаются из клетки [16]. При этом фенольные вещества и флавоноиды сохраняют высокую антирадикальную активность и восстанавливающую силу. 
Таблица 1. Изучение химического состава вторичного виноградного сырья

\begin{tabular}{c|c|c|c|c}
\hline \multirow{2}{*}{ Температура сушки, ${ }^{\circ} \mathrm{C}$} & \multicolumn{4}{|c}{ Показатели } \\
\cline { 2 - 5 } & $\begin{array}{c}\text { Фенольные } \\
\text { вещества, мг ГК/100 г } \\
\text { исходного сырья }\end{array}$ & $\begin{array}{c}\text { Флавоноиды, мг } \\
\text { К } / 100 \text { г } \\
\text { исходного сырья }\end{array}$ & $\begin{array}{c}\text { Антоцианы, мг } \\
\text { ЦГ } / 100 \text { г } \\
\text { исходного сырья }\end{array}$ & $\begin{array}{c}\text { Танины, мг К/100 г } \\
\text { исходного сырья }\end{array}$ \\
\hline Свежие мякоть и кожица & $1,77 \pm 0,03$ & $0,81 \pm 0,06$ & $647,7 \pm 3,2$ & $34,50 \pm 0,9$ \\
$50-52$ & $2,24 \pm 0,05$ & $2,07 \pm 0,02$ & $964,4 \pm 3,8$ & $101,92 \pm 1,3$ \\
$100-102$ & $1,94 \pm 0,03$ & $1,53 \pm 0,05$ & $97,5 \pm 0,9$ & $62,72 \pm 0,8$ \\
$130-132$ & $2,16 \pm 0,04$ & $1,52 \pm 0,04$ & $257,8 \pm 2,1$ & $55,72 \pm 0,6$ \\
Сублимационная сушка & $0,4 \pm 0,02$ & $0,23 \pm 0,01$ & $980 \pm 3,4$ & $65,5 \pm 1,1$ \\
Свежие косточки & $7,51 \pm 0,11$ & $6,9 \pm 0,2$ & - & $36,84 \pm 0,5$ \\
$50-52$ & $7,84 \pm 0,27$ & $7,05 \pm 1,24$ & - & $72,80 \pm 0,9$ \\
$100-102$ & $6,67 \pm 0,09$ & $5,8 \pm 0,15$ & - & $42,80 \pm 1,1$ \\
$130-132$ & $4,49 \pm 0,02$ & $3,81 \pm 0,08$ & - & $22,34 \pm 0,4$ \\
Сублимационная сушка & $5,91 \pm 0,17$ & $5,09 \pm 0,12$ & 74,6 \\
Свежие выжимки & $2,72 \pm 0,03$ & $2,29 \pm 0,06$ & $746 \pm 3,3$ & $11,40 \pm 0,3$ \\
$50-52$ & $3,32 \pm 0,04$ & $3,05 \pm 0,1$ & $659 \pm 2,7$ & $83,40 \pm 0,8$ \\
$100-102$ & $2,84 \pm 0,01$ & $3,01 \pm 0,07$ & $103,4 \pm 1,9$ & $73,80 \pm 1,7$ \\
$130-132$ & $2,26 \pm 0,03$ & $2,01 \pm 0,04$ & $227,3 \pm 2,3$ & $46,70 \pm 0,9$ \\
Сублимационная сушка & $0,69 \pm 0,02$ & $1,09 \pm 0,03$ & $1069 \pm 3,9$ & $15,92 \pm 0,5$ \\
\hline
\end{tabular}

Анализируя полученные данные рисунка 1, можно проследить, что при взаимодействии тепловой обработки на растительные клетки снижается антиокислительная способность вторичного виноградного сырья по сравнению с исходным сырьем, а при сублимационном способе сушки антиокислительная способность практически остается неизменной. Это объясняется тем, что в растительных клетках антиокислительной активностью обладают не только фенольные вещества, флавоноиды, но также ферментные системы клетки и витамины C, А, E [17]. При нагревании эти антиоксиданты разрушаются и остается антиокислительная активность, присущая фенольному комплексу антиоксидантов.

Таким образом, по химическому составу мы можем выделить мякоть и кожицу, косточки, выжимки, высушенные при температуре $50-52{ }^{\circ} \mathrm{C}$, которые содержат оптимальное количество фенолов, флавоноидов, антоцианов и танинов. Также можно сделать вывод, что вторичное сырье винограда, высушенное при температуре 50-52 ${ }^{\circ} \mathrm{C}$, имеют более высокие показатели антиоксидантной активности (рис. 2).

На основании экспериментальных данных в качестве режимов сушки вторичного виноградного сырья были выбраны технологические режимы процесса сушки вторичного виноградного сырья: конвективная сушка при $50-52{ }^{\circ} \mathrm{C}$ в течение 24 ч.

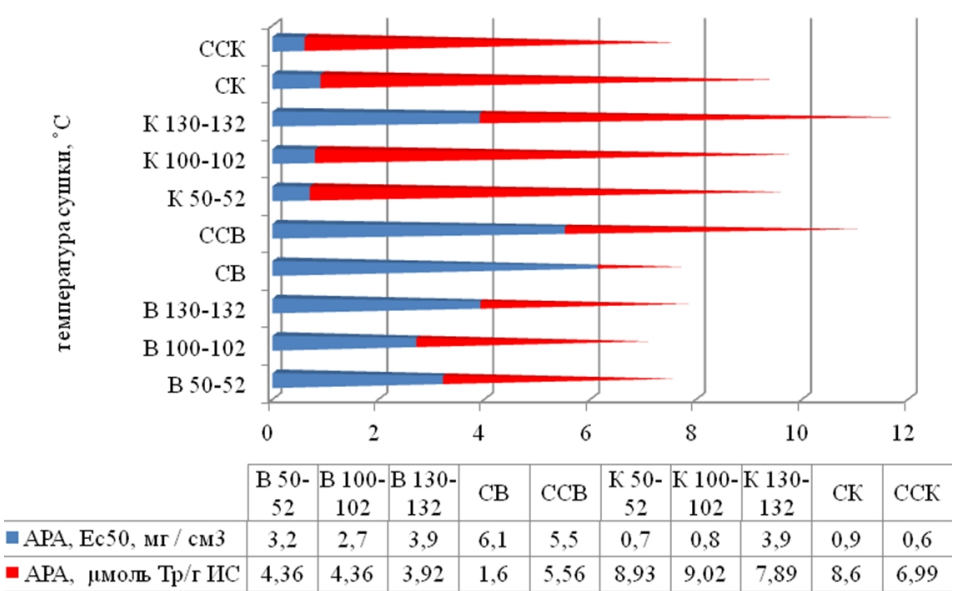

Рис. 1. Оценка антиоксидантных свойств вторичного виноградного сырья после тепловой обработки: ССК - сублимационная сушка косточек, СК - свежие косточки, К - косточки, ССВ - сублимационная сушка выжимки, СВ - свежие выжимки, В - выжимки

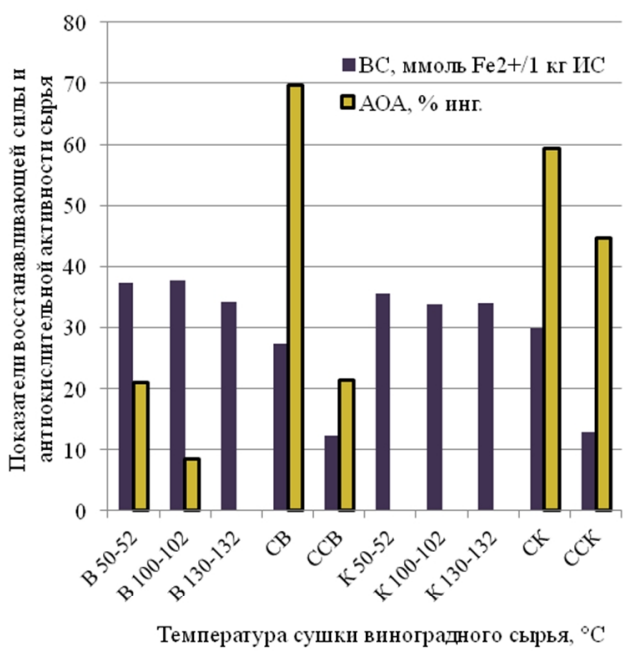

Рис. 2. Изучение антиоксидантных свойств вторичного виноградного сырья 
Процесс экстракции в пищевой промышленности растительных материалов является сложным многофакторным процессом. Одним из важнейших факторов является природа используемого растворителя для экстракции [18-20]. Кроме этого, обнаружена взаимосвязь между природой растворителя для экстракции и антирадикальными свойствами экстрактов вторичного виноградного сырья [21]. С целью определения оптимального растворителя для получения экстрактов из виноградного сырья использовались наиболее безопасные и экологически безвредные экстрагенты: вода, этиловый спирт, смесь воды и этилового спирта в соотношениях: $\mathrm{H}_{2} \mathrm{O} ; 30 \% \mathrm{C}_{2} \mathrm{H}_{5} \mathrm{OH}+70 \% \mathrm{H}_{2} \mathrm{O} ; 50 \% \mathrm{C}_{2} \mathrm{H}_{5} \mathrm{OH}+50 \% \mathrm{H}_{2} \mathrm{O} ; 70 \% \mathrm{C}_{2} \mathrm{H}_{5} \mathrm{OH}+30 \% \mathrm{H}_{2} \mathrm{O}$; $\mathrm{C}_{2} \mathrm{H}_{5} \mathrm{OH}$ с концентрацией спирта $96 \%$.

Для определения оптимальной величины гидромодуля измельченное высушенное сырье заливали растворителем в соотношении сырье : экстрагент 1 : 10 (по массе), выдерживали при комнатной температуре в течение 2 ч при периодическом перемешивании и отделяли экстракт. В полученных виноградных экстрактах определяли общее содержание фенольных веществ, флавоноидов, танинов, антоцианов, а также антиоксидантную активность. Результаты определения представлены в таблице 2 и на рисунках 3 и 4 .

Был проведен качественный и количественный анализ состава экстрактов вторичного виноградного сырья с повышенным содержанием биологически активных веществ. Из таблицы 2 следует, что с увеличением концентрации спирта до 70\% увеличивается общее число фенолов, флавоноидов, танинов и антоцианов в экстрактах выжимок винограда.

Таблица 2. Исследование растворителя для виноградных выжимок и косточек

\begin{tabular}{|c|c|c|c|c|}
\hline \multirow{2}{*}{ Растворитель } & \multicolumn{4}{|c|}{ Показатели } \\
\hline & ФВ, мг ГК/100 г ИС & Фл, мг К/100 г ИС & Ац, мг ЦГ/100 г ИС & Т, мг К/100 г ИС \\
\hline \multicolumn{5}{|c|}{ Мякоть и кожица } \\
\hline Контроль & $1,49 \pm 0,01$ & $1,31 \pm 0,01$ & $329,6 \pm 2,9$ & $13,80 \pm 0,9$ \\
\hline $30 \% \mathrm{C}_{2} \mathrm{H}_{5} \mathrm{OH}$ & $2,18 \pm 0,03$ & $1,86 \pm 0,02$ & $661,7 \pm 3,6$ & $45,90 \pm 1,1$ \\
\hline $50 \% \mathrm{C}_{2} \mathrm{H}_{5} \mathrm{OH}$ & $2,24 \pm 0,04$ & $2,06 \pm 0,04$ & $882,3 \pm 3,8$ & $64,30 \pm 1,3$ \\
\hline $70 \% \mathrm{C}_{2} \mathrm{H}_{5} \mathrm{OH}$ & $2,41 \pm 0,02$ & $2,17 \pm 0,06$ & $1132,5 \pm 4,1$ & $72,80 \pm 1,6$ \\
\hline $96 \% \mathrm{C}_{2} \mathrm{H}_{5} \mathrm{OH}$ & $2,1 \pm 0,01$ & $1,88 \pm 0,02$ & $583,1 \pm 3,1$ & $65,20 \pm 1,2$ \\
\hline \multicolumn{5}{|c|}{ Косточки } \\
\hline Контроль & $4,95 \pm 0,08$ & $2,18 \pm 0,07$ & - & $14,80 \pm 0,8$ \\
\hline $30 \% \mathrm{C}_{2} \mathrm{H}_{5} \mathrm{OH}$ & $7,88 \pm 0,24$ & $6,96 \pm 0,17$ & - & $36,72 \pm 1,1$ \\
\hline $50 \% \mathrm{C}_{2} \mathrm{H}_{5} \mathrm{OH}$ & $7,33 \pm 0,21$ & $7,04 \pm 0,19$ & - & $72,80 \pm 1,4$ \\
\hline $70 \% \mathrm{C}_{2} \mathrm{H}_{5} \mathrm{OH}$ & $7,63 \pm 0,36$ & $7,06 \pm 0,21$ & - & $52,16 \pm 1,2$ \\
\hline $96 \% \mathrm{C}_{2} \mathrm{H}_{5} \mathrm{OH}$ & $8,39 \pm 0,41$ & $7,57 \pm 0,22$ & - & $87,36 \pm 1,8$ \\
\hline \multicolumn{5}{|c|}{ Выжимки } \\
\hline Контроль & $2,17 \pm 0,05$ & $1,8 \pm 0,02$ & $348,5 \pm 2,4$ & $14,12 \pm 0,7$ \\
\hline $30 \% \mathrm{C}_{2} \mathrm{H}_{5} \mathrm{OH}$ & $3,46 \pm 0,09$ & $3,16 \pm 0,07$ & $689,1 \pm 3,4$ & $42,80 \pm 1,2$ \\
\hline $50 \% \mathrm{C}_{2} \mathrm{H}_{5} \mathrm{OH}$ & $3,62 \pm 0,08$ & $3,22 \pm 0,05$ & $912,2 \pm 3,9$ & $68,30 \pm 1,4$ \\
\hline $70 \% \mathrm{C}_{2} \mathrm{H}_{5} \mathrm{OH}$ & $4,21 \pm 0,12$ & $3,12 \pm 0,06$ & $1145,2 \pm 4,2$ & $69,45 \pm 1,3$ \\
\hline $96 \% \mathrm{C}_{2} \mathrm{H}_{5} \mathrm{OH}$ & $6,04 \pm 0,19$ & $3,42 \pm 0,04$ & $612,3 \pm 3,5$ & $72,56 \pm 1,5$ \\
\hline
\end{tabular}

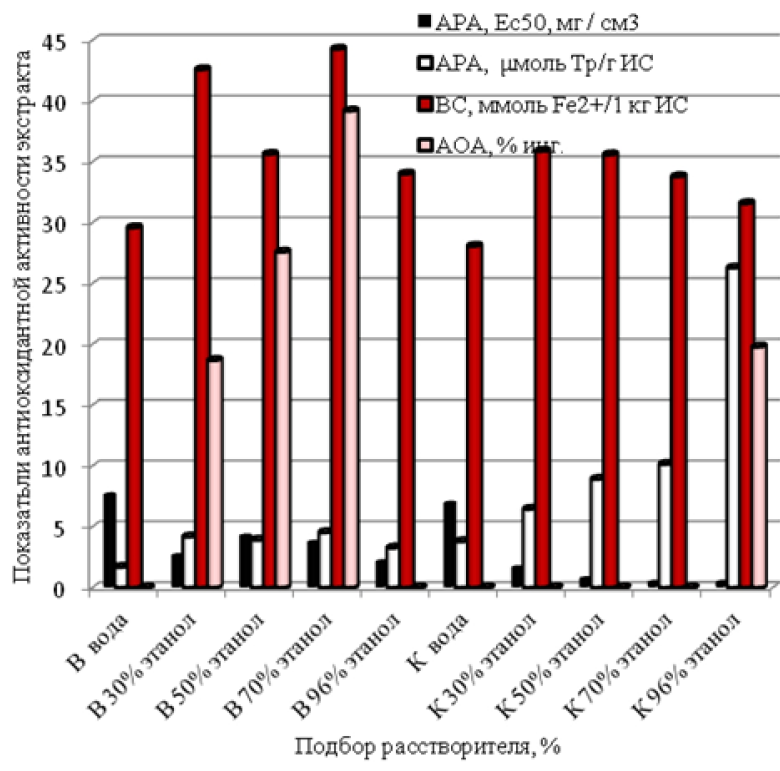

Рис. 3. Изучение антиоксидантных свойств экстракта 

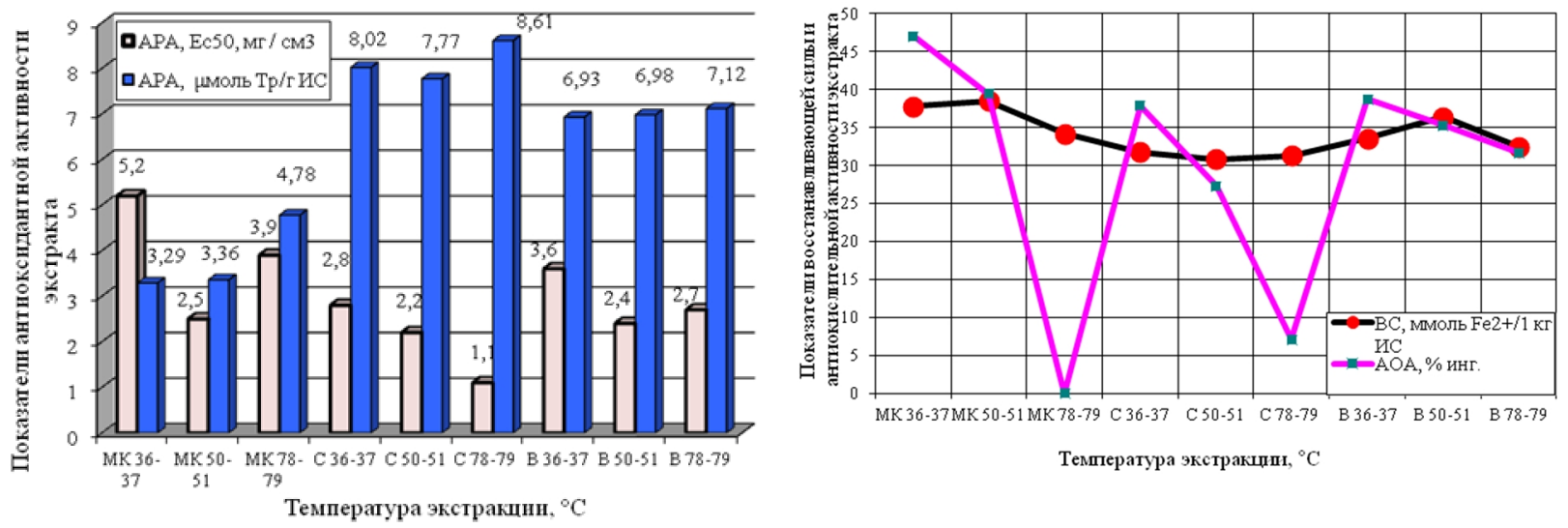

Рис. 4. Изучение антиоксидантных свойств экстракта

Для оценки подбора растворителя экстракта вторичного виноградного сырья был использован критериальный подход, основные положения которого состоят в следующем. Исходя из первоначальных данных о содержании антиоксидантов в сырье и проявляемой активности экстрактов с различной концентрацией растворителя, были подсчитаны критериальные коэффициенты антиоксидантности (ККА). При сравнении сумм критериальных коэффициентов антиоксидантности для каждой пары «сырье - растворитель» с ККА экстракта, подсчитанных на основании полученных экспериментальных данных, можно сделать вывод о наличии или отсутствии синергизма действия антиоксидантов, содержащихся в разных растительных источниках. Результаты экспериментальных данных по определению содержания антиоксидантов и подсчитанных ККА для экстрактов выжимок винограда, полученных с использованием различных растворителей, приведены в таблице 3 .

На примере экстракта выжимок винограда (табл. 3) видно, что суммарные коэффициенты антиоксидантной активности экстракта выжимок винограда с различной концентрацией растворителя не совпадают по числовому значению с суммарными коэффициентами антиоксидантной активности контроля. Так, по убыванию критериальных коэффициентов антиоксидантности экстракты выжимок винограда с различной концентрацией спирта можно расположить в следующем порядке: $70 \% \mathrm{C}_{2} \mathrm{H}_{5} \mathrm{OH}>96 \% \mathrm{C}_{2} \mathrm{H}_{5} \mathrm{OH}>50 \%$ $\mathrm{C}_{2} \mathrm{H}_{5} \mathrm{OH}>30 \% \mathrm{C}_{2} \mathrm{H}_{5} \mathrm{OH}>\mathrm{H}_{2} \mathrm{O}$. Таким образом, следует отметить, что при увеличении концентрации спирта до $70 \% \mathrm{C}_{2} \mathrm{H}_{5} \mathrm{OH}$ увеличиваются числовые значения ККА экстракта, что может свидетельствовать о наличии синергизма действия антиоксидантов данных объектов исследования.

Для экстракта косточек винограда оптимальным растворителем можно считать 96\% $\mathrm{C}_{2} \mathrm{H}_{5} \mathrm{OH}$, так как при использовании данных концентраций спирта обеспечивается наибольшее количество фенольных веществ, флавоноидов, танинов, восстанавливающей силы. Кроме этого, при данной концентрации спирта экстракт проявляет наивысшие антирадикальные показатели (рис. 3).

Полученные результаты позволяют сделать вывод о том, что 70\% $\mathrm{C}_{2} \mathrm{H}_{5} \mathrm{OH}$ является технологически обоснованным для получения экстрактов из мякоти и кожицы винограда, выжимок винограда, с максимальным содержанием фенольных веществ, антоцианов, танинов, флавоноидов и антиоксидантной активностью. А для получения экстракта из косточек винограда таким растворителем является $96 \% \mathrm{C}_{2} \mathrm{H}_{5} \mathrm{OH}$.

Также важное влияние на процесс экстракции оказывает температура экстракции. Так, в статье сообщается, что температура изменяет состояние процианидинового комплекса виноградных выжимок и косточек $[22,23]$.

С целью определения оптимальной температуры экстракции были исследованы три варианта температур: 36-37, 50-51, 78-79 ${ }^{\circ}$, с использованием 70\% $\mathrm{C}_{2} \mathrm{H}_{5} \mathrm{OH}$ для экстрактов из мякоти и кожицы винограда, выжимок винограда и 96\% $\mathrm{C}_{2} \mathrm{H}_{5} \mathrm{OH}$ экстракта из косточек винограда. Экстракцию проводили в течение 2 ч.

Полученные результаты общего содержания фенолов, флавоноидов, танинов и антоцианов представлены в таблице 4 и на рисунке 4.

Полученные результаты (табл. 4) свидетельствуют о том, что оптимальной температурой экстракции для получения экстрактов из мякоти и кожицы винограда, с максимальными показателями, является температура $78-79$ $\mathrm{C}$. Для антоцианов наиболее благоприятна низкая температура. 
Таблица 3. Содержание антиоксидантов, антиоксидантные свойства и критериальные коэффициенты антиоксидантной активности экстрактов выжимок винограда

\begin{tabular}{l|c|c|c|c|c}
\hline \multicolumn{1}{c|}{ Показатели } & $\mathrm{H}_{2} \mathrm{O}$ & $30 \% \mathrm{C}_{2} \mathrm{H}_{5} \mathrm{OH}$ & $50 \% \mathrm{C}_{2} \mathrm{H}_{5} \mathrm{OH}$ & $70 \% \mathrm{C}_{2} \mathrm{H}_{5} \mathrm{OH}$ & $96 \% \mathrm{C}_{2} \mathrm{H}_{5} \mathrm{OH}$ \\
\hline ФВ, мГ ГК/100 г ИС & $2,17 \pm 0,05$ & $3,46 \pm 0,09$ & $3,62 \pm 0,08$ & $4,21 \pm 0,12$ & $6,04 \pm 0,19$ \\
ККА 1 & 0,35 & 0,57 & 0,6 & 0,69 & 1 \\
Фл, мГ К/100 г ИС & $1,8 \pm 0,02$ & $3,16 \pm 0,07$ & $3,22 \pm 0,05$ & $3,12 \pm 0,06$ & $3,42 \pm 0,04$ \\
ККА 2 & 0,52 & 0,92 & 0,94 & 0,91 & 1 \\
АЦ, мГ ЦГ/100 г ИС & $348,5 \pm 2,4$ & $689,1 \pm 3,4$ & $912,2 \pm 3,9$ & $1145,2 \pm 4,2$ & $612,3 \pm 3,5$ \\
ККА 3 & 0,3 & 0,6 & 0,79 & 1 & 0,53 \\
Т, мГ К/100 г ИС & $14,12 \pm 0,7$ & $42,8 \pm 1,2$ & $68,3 \pm 1,3$ & $69,45 \pm 1,3$ & $72,56 \pm 1,5$ \\
ККА 4 & 0,2 & 0,59 & 0,94 & 0,96 & 1 \\
\hline \multicolumn{5}{c}{ Суммарные ККА } & \multicolumn{3}{c}{$1,37 \pm 0,8$} \\
\hline
\end{tabular}

Таблица 4. Результаты исследования общего содержания фенольных веществ, флавоноидов, танинов и антоцианов от температуры экстракции

\begin{tabular}{|c|c|c|c|c|}
\hline \multirow{2}{*}{$\begin{array}{c}\text { Температура } \\
\text { экстракции, }{ }^{\circ} \mathrm{C}\end{array}$} & \multicolumn{4}{|c|}{ Показатели } \\
\hline & ФВ, мГ ГК/100 г ИС & Фл, мг К/100 г ИС & Ац, мг ЦГ/100 г ИС & Т, мг К/100 г ИС \\
\hline \multicolumn{5}{|c|}{ Мякоть и кожица } \\
\hline $36-37$ & $2,9 \pm 0,05$ & $1,78 \pm 0,01$ & $1006,5 \pm 5,6$ & $64,40 \pm 1,3$ \\
\hline $50-51$ & $2,19 \pm 0,03$ & $2,01 \pm 0,03$ & $953,9 \pm 5,1$ & $63,28 \pm 1,1$ \\
\hline $78-79$ & $3,36 \pm 0,07$ & $2,51 \pm 0,06$ & $680,6 \pm 3,8$ & $67,06 \pm 1,2$ \\
\hline \multicolumn{5}{|c|}{ Косточки } \\
\hline $36-37$ & $9,51 \pm 0,56$ & $7,31 \pm 0,39$ & - & $84,20 \pm 1,7$ \\
\hline $50-51$ & $9,01 \pm 0,49$ & $7,33 \pm 0,37$ & - & $85,82 \pm 1,9$ \\
\hline $78-79$ & $8,81 \pm 0,41$ & $6,95 \pm 0,31$ & - & $70,28 \pm 1,5$ \\
\hline \multicolumn{5}{|c|}{ Выжимки } \\
\hline $36-37$ & $3,41 \pm 0,09$ & $2,81 \pm 0,04$ & $986,4 \pm 4,9$ & $72,40 \pm 1,5$ \\
\hline $50-51$ & $3,73 \pm 0,07$ & $3,21 \pm 0,05$ & $812,7 \pm 4,6$ & $75,20 \pm 1,6$ \\
\hline $78-79$ & $3,64 \pm 0,08$ & $3,18 \pm 0,04$ & $596,2 \pm 3,1$ & $69,8 \pm 1,4$ \\
\hline
\end{tabular}

Ранжируя полученные данные, можно сделать вывод о том, что технологически обоснованная температура экстракции для выжимок винограда составляет $50-51^{\circ} \mathrm{C}$. Дальнейшее повышение температуры, согласно экспериментальным данным, не способствует увеличению полноты экстракции и вызывает разрушение биологически активных соединений (фенольных веществ, витаминов).

С целью определения технологически обоснованной продолжительности процесса экстракцию проводили в течение 1, 2 и 3 ч с использованием 70\% $\mathrm{C}_{2} \mathrm{H}_{5} \mathrm{OH}$ для экстрактов из мякоти и кожицы винограда, выжимок винограда и 96\% $\mathrm{C}_{2} \mathrm{H}_{5} \mathrm{OH}$ для экстракта из косточек винограда. Экстрагирование проводили при температуре $50-51{ }^{\circ} \mathrm{C}$. В полученных извлечениях определяли содержание общего химического состава (табл. 5) и антиоксидантную активность (рис. 5).

Полученные данные позволяют сделать вывод о том, что технологически обоснованная продолжительность экстракции для мякоти и кожицы, выжимок, косточек винограда составляет 2 ч, более длительное экстрагирование приводит к разрушению фенольных веществ.

Одной из основных стадий получения экстрактов косточек винограда является сам процесс экстракции [24]. От правильного подбора параметров концентрирования экстрактов зависит химический состав и антиоксидантная активность экстрактов.

Исходя из таблицы 6, можно сделать вывод, что концентрированные экстракты под вакуумом превосходят по показателям химического состава и антиоксидантным свойствам экстракты, полученные при обычных условиях.

В результате полученных исследований технологически обоснованные параметры экстракции вторичного виноградного сырья можно сформулировать следующим образом (табл. 7). 
Таблица 5. Результаты исследования продолжительности экстракции на химический состав

\begin{tabular}{|c|c|c|c|c|}
\hline \multirow{2}{*}{ Время экстракции, ч } & \multicolumn{4}{|c|}{ Показатели } \\
\hline & ФВ, мг ГК/100 г ИС & Фл, мг К/100 г ИС & Ащ, мГ ЦГ/100 г ИС & Т, мг К/100 г ИС \\
\hline \multicolumn{5}{|c|}{ Мякоть и кожица } \\
\hline 1 & $2,19 \pm 0,03$ & $2,01 \pm 0,03$ & $953,9 \pm 5,1$ & $63,28 \pm 1,1$ \\
\hline 2 & $2,08 \pm 0,02$ & $1,88 \pm 0,01$ & $972,1 \pm 4,9$ & $64,7 \pm 1,2$ \\
\hline 3 & $2,04 \pm 0,02$ & $1,75 \pm 0,01$ & $964,2 \pm 4,7$ & $64,1 \pm 1,2$ \\
\hline \multicolumn{5}{|c|}{ Выжимки } \\
\hline 1 & $3,73 \pm 0,07$ & $3,21 \pm 0,05$ & $812,7 \pm 4,6$ & $75,20 \pm 1,6$ \\
\hline 2 & $3,94 \pm 0,08$ & $3,37 \pm$ & $826,7 \pm 4,8$ & $77,1 \pm 1,5$ \\
\hline 3 & $3,86 \pm 0,06$ & $3,29 \pm$ & $819,1 \pm 4,5$ & $76,2 \pm 1,3$ \\
\hline \multicolumn{5}{|c|}{ Косточки } \\
\hline 1 & $9,01 \pm 0,49$ & $7,33 \pm 0,37$ & - & $85,2 \pm 1,9$ \\
\hline 2 & $9,67 \pm 0,59$ & $7,61 \pm 0,42$ & - & $87,1 \pm 1,8$ \\
\hline 3 & $9,61 \pm 0,52$ & $7,99 \pm 0,43$ & - & $86,2 \pm 1,6$ \\
\hline
\end{tabular}
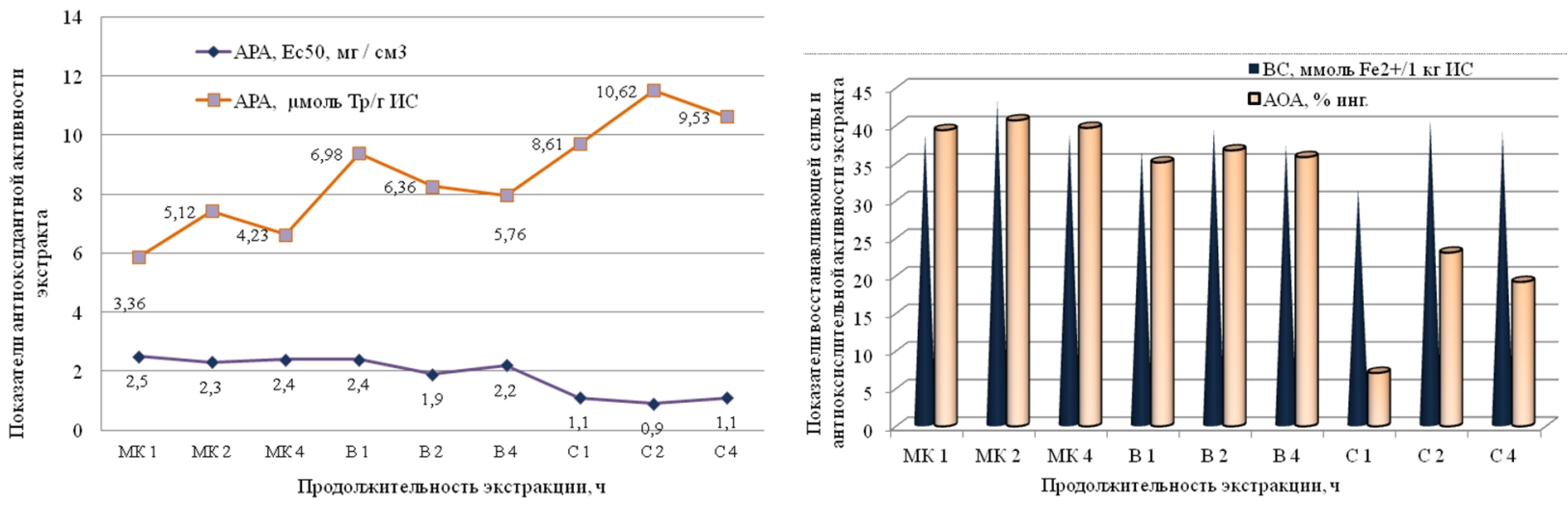

Рис. 5. Изучение антиоксидантных свойств экстракта

Таблица 6. Результаты исследования химического состава концентрированных экстрактов

\begin{tabular}{l|c|c|c}
\hline \multirow{2}{*}{\multicolumn{1}{c|}{ Показатели }} & \multicolumn{3}{|c}{ Концентрирование } \\
\cline { 2 - 4 } & $\begin{array}{c}\text { Экстракт мякоти } \\
\text { и кожицы } \\
\omega_{\text {сух.в-в }}=65 \% \pm 0,1\end{array}$ & $\begin{array}{c}\text { Экстракт выжимок } \\
\omega_{\text {сух. в-в }}=63 \% \pm 0,1\end{array}$ & $\begin{array}{c}\text { Экстракт косточек } \\
\omega_{\text {сух. в-в }}=67 \% \% \pm 0,1\end{array}$ \\
\hline Антирадикальная активность, Ес50, мг/см & 2,9 & 1,1 & 0,09 \\
Антирадикальная активность, $\mu$ моль Тр/г ИС & 58,6 & 134,7 & 155,5 \\
Восстанавливающая сила, ммоль Fе2+/1 кгИС & 34,27 & 32,13 & 39,08 \\
Антиокислительная активность, \% инг. & 4,7 & Не обнаружена & Не обнаружена \\
Фенольные вещества, мг ГК/100 г ИС & 2,75 & 4,78 & 11,5 \\
Флавоноиды, мг К/100 г ИС & 1,92 & 3,02 & 8,6 \\
Танины, мг К/100 г ИС & 103,1 & 127,1 & 157,75 \\
Антоцианы, мГ ЦГ/100 г ИС & 512,6 & 415,4 & - \\
\hline
\end{tabular}

Таблица 7. Параметры экстракции

\begin{tabular}{l|c|c|c}
\hline \multicolumn{1}{c|}{ Параметры } & \multicolumn{3}{|c}{ Экстракт } \\
\cline { 2 - 4 } & Мякоть, кожица & Косточки & Выжимки \\
\hline Температура сушки, ${ }^{\circ} \mathrm{C}$ & $50-52$ & $50-52$ & $50-52$ \\
Растворитель & $70 \% \mathrm{C}_{2} \mathrm{H}_{5} \mathrm{OH}$ & $96 \% \mathrm{C}_{2} \mathrm{H}_{5} \mathrm{OH}$ & $70 \% \mathrm{C}_{2} \mathrm{H}_{5} \mathrm{OH}$ \\
Температура экстракции, ${ }^{\circ} \mathrm{C}$ & $78-79$ & $36-37$ & $50-51$ \\
Время экстракции, ч & 2 & 2 & 2 \\
Процесс экстракции & \multicolumn{2}{|c|}{ Концентрирование под вакуумом } \\
\hline
\end{tabular}

В результате проведенных исследований была разработана технология получения экстрактов из вторичного виноградного сырья, процессуальная схема которой представлена на рисунке 6. На основании проведенных исследований выбраны технологические режимы процесса получения экстракта: конвективная сушка сырья при $50{ }^{\circ} \mathrm{C} 24$ ч, температура экстракции $-50-51{ }^{\circ} \mathrm{C}$, время экстракции - 2 ч, концентрирование под вакуумом. 


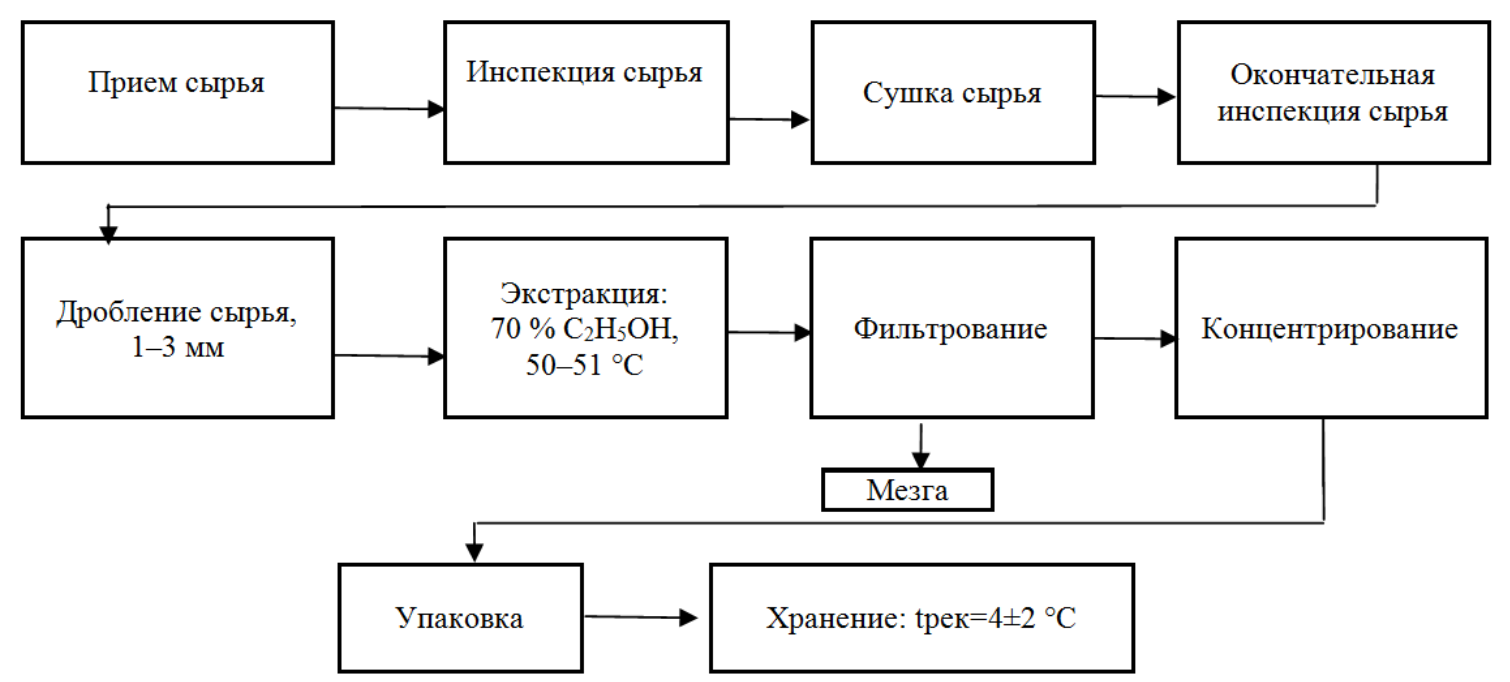

Рис. 6. Блок-схема получения экстракта из выжимок винограда

\section{Bbыводbl}

1. При производстве растительного экстракта важное значение на химические свойства и антиоксидантные показатели оказывает выбор объектов виноградного сырья.

2. При приготовлении экстракта из вторичного виноградного сырья наиболее благоприятно на химические свойства и антирадикальные показатели влияют стадии сушки сырья, кроме этого, сушка позволяет увеличить сроки хранения отходов винодельческого предприятия, а также повысить содержание фенольных веществ и флавоноидов.

3. Использование $70 \% \mathrm{C}_{2} \mathrm{H}_{5} \mathrm{OH}$ является технологически обоснованным для производства экстракта выжимок винограда, с повышенным содержанием фенольных веществ, танинов, флавоноидов, антоцианов и антиоксидантной активностью.

4. Технологически обоснованная температура экстракции для выжимок винограда $-50-51{ }^{\circ} \mathrm{C}$. Дальнейшее повышение температуры не способствует увеличению полноты экстракции и, согласно экспериментальным данным, вызывает разрушение биологически активных соединений. Поэтому повышение температуры в данном случае нецелесообразно.

5. Оптимальная продолжительность экстракции для вторичного виноградного сырья составляет 2 ч, с увеличением времени экстракции происходит истощение сырья, что приводит к уменьшению выхода биологически активных веществ.

6. Концентрирование под вакуумом является более предпочтительным методом перед другими, поскольку при данном режиме лучше сохраняются фенольные вещества, флавоноиды и антиоксидантная активность. Также при данном процессе наблюдается высокое содержание танинов.

\section{Список литературы}

1. Кустова И.А., Макарова Н.В., Календарева Е.В. Подбор температуры для получения экстрактов из выжимок винограда с высокой антиокислительной активностью // Качество и экологическая безопасность пищевых продуктов: III международная научная конференция с элементами научной школы для молодежи. 2015. C. 44-48.

2. Karre L., Lopez K., Getty Kelly J.K. Natural antioxidants in meat and poultry products // Meat Sci. 2013. Vol. 94, N2. Pp. 220-227.

3. Özvural E.B., Vural H. Grape seed flour is a viable ingredient to improve the nutritional profile and reduce lipid oxidation of frankfurters // Meat Sci. 2011. Vol. 88, N1. Pp. 179-183.

4. Kulkarni S., DeSantos F.A., Kattamuri S., Rossi S.J., Brewer M.S. Effect of grape seed extract on oxidative, color and sensory stability of a pre-cooked, frozen, re-heated beef sausage model system // Meat Sci. 2011. Vol. 88, N1. Pp. 139-144. 
5. Choi Y.-S., Choi J.-H., Han D.-J., Kim H.-Y, Lee M.-A., Kim H.-W., Lee J.-W., Chung H.-J., Kim C.-J. Optimization of replacing pork back fat with grape seed oil and rice bran fiber for reduced-fat meat emulsion systems // Meat Sci. 2010. Vol. 84, N1. Pp. 212-218.

6. Rababah T., Hettiarachchy N.S., Eswaranandam S., Meullenet J.F., Davis B. Sensory evaluation of irradiated and nonirradiated poultry breast meat infused with plant extracts // J. Food Sci. 2005. Vol. 70, N3. Pp. S228-S235.

7. Jungmin L., Chrictopher R. Influence of extraction methodology on grape composition values // Food Chem. 2011. Vol. 126, N1. Pp. 295-300.

8. Rockenbach I.I., Rodrigues E., Gonzaga L.V., Caliari V., Genovese M.I., Schmidt G., Fett R. Phenolic compunds content and antioxidant activity in pomace from selected red grapes (Vitis vinifera L. and Vitis Labrusca L.) widely produced in Brazil // Food Chem. 2011. Vol. 127, N1. Pp. 174-179.

9. Skerget M., Kotnik P., Hadolin M., Hras A.R., Simonic M., Knez Z. Phenols, proanthocyanidins, flavones and flavonols in some plant materials and their antioxidant activities // Food Chem. 2005. Vol. 89, N1. Pp. 191-198.

10. Crespy A. Tannins de pepins de raisin: possibilites de stabilization de la couleur, de protection contre l'oxydation et d'amelioration de la tenue en boushe sur vins rouges et roses // Rev. fr. oenol. 2002. Vol. 30, N195. Pp. 23-27.

11. Obradovic D., Oatey M., Schulz M., Enhanced stabilisation of anthocyanin compounds // Austral. and N.Z. Grapegrow. and Winemaker. 2005. N498. Pp. 51-53.

12. Rufino M.S.M., Fernandes F.A.N., Alves R.E., de Brito E.S. Free radical-scavenging behavior of some north-east Brazilian fruits // Food Chem. 2009. Vol. 114, N4. Pp. 693-695.

13. Mariken J.T.J., Sebastiaan Dallinga J., Hans-Peter V., Guido R.M.M., Aalt B. A new approach to assess the total antioxidant capacity using the TEAC assay // Food Chem. 2004. Vol. 88, N4. Pp. 567-570.

14. Nilsson J., Stegmark R., Akesson B. Total antioxidant capacity in different pea (Pisum sativum) varieties after blanching and freezing // Food Chem. 2004. Vol. 86, N3. Pp. 501-507.

15. Qing L., Huiyuan Y. Antioxidant activities of barley seeds extracts // Food Chem. 2007. Vol. 102, N3. Pp. $732-737$.

16. Brett C.T., Waldron E.K. Physiology and biochemistry of plant cell wall. Eds. Black M., Cahapman E.J. London: Unwin Hyman, 1990. 194 p.

17. Абдулин И.Ф., Турова Е.Н., Будников Г.К. Органические антиоксиданты как объекты анализа // Заводская лаборатория. Диагностика материалов. 2001. Т. 167, №6. С. 3-13.

18. Ju Zhi Y., Howard Luke R. Subcritical water extraction of anthocyanins and other phenolics from dried red grape skin // J. Food Sci. 2005. Vol. 70, N4. Pp. 270-276.

19. Garcia-Marino M., Rivas-Gonzalo Julian C., Ibanez E., Garcia-Moreno C. Recovery of catechins and proanthocyanidins from winery by- products using subcritical water extraction // Anal. chim. acta. 2005. Vol. 563, N1-2. Pp. 44-50.

20. Floris T., Filippino G., Scrugli S., Pinna M. B., Argiolas A., Murru M., Reverchon E. Antoxidant compounds recovery from grape residues by a supercritical antisolvent assisted process // J. Supercrit. Fluids. 2010. Vol. 54, N2. Pp. 165-170.

21. Spigno G., Tramelli L., De Faveri D. M. Effects of extraction time, temperature and solvent on concentration and antioxidant activity of grape marc phenolics // J. Food Eng. 2007. Vol. 81, N4. Pp. 200-208.

22. Гапенко Ю.В., Зайко Г.М., Агеева Н.М., Марковский М.Г. Изменение процианидинового комплекса виноградной выжимки при кулинарной обработке // Известия вузов. Пищевые технологии. 2004. №2-3. С. 39-40.

23. Khanal Ramesh C., Howard Luke R., Prior Ronald L. Procyanidin composition of selected fruits and fruit byproducts is affected by extraction method and variety // J. Agr. and Food Chem. 2009. Vol. 57, N19. Pp. 8839-8843.

24. Тагирова П.Р., Касьянов Д.Г. Переработка виноградных выжимок и виноградных семян с использованием жидкого диоксида углерода // Известия вузов. Пищевые технологии. 2010. №2-3. С. 60-62.

Поступило в редакиию 18 декабря 2016 г. 

RIALS

Kustova I.A. , Makarova N.V., Gudkova A.M. OBTAINING EXTRACT FROM GRAPE SECONDARY RAW MATE-

Samara state technical University, Molodogvardeyskaya st. 244, Samara, 443100 (Russia),

e-mail: batkova_ira7@mail.ru

The problem of environmental degradation, the impact on the body external adverse factors leads to the accumulation in the body of free radicals, products of incomplete reduction of oxygen, an excess of which leads to lipid peroxidation and as a consequence of dysfunction of cellular membranes. This leads to the formation of numerous diseases. Therefore, an important trend in the food industry is the production of food with high content of biologically active substances. Considered the issues of influence of technological parameters on the properties of the extract: chemical composition, antiradical, antioxidant activity, restoring force. The results of the selection of the optimal drying temperature secondary grapes, the optimal solvent, the optimum temperature of extraction, duration of extraction and the extraction process. In this paper various techniques are used to determine the level of antioxidant activity: the total content of phenolic compounds equivalent to Gallic acid, flavonoids and tannins equivalent of catechin, anthocyanins, the equivalent of cyanidin-3-glycoside, antiradical capacity using the free radical DPPH (2,2-diphenyl-1-picrylhydrazyl) $\mathrm{mg} / \mathrm{ml}$, antioxidant activity by the method of ABTS (2,2'-Azino-bis(3ethylbenzothiazoline-6-sulfonic acid) mol of trolox, restoring force by the method of FRAP with 2,4,6-trierer-5-triazine, antioxidant activity in the linoleic acid system. The result revealed that the development of technology of extract from secondary grapes most significantly to polyphenol and antioxidant indexes influence the drying step of the raw material, in addition, drying allows to increase the shelf life of recycled materials, minimize waste enterprises, and to increase the content of phenolic compounds and flavonoids. It is shown that the use of certain drying temperatures of the feedstock, the duration and temperature of extraction using mixture of ethanol-water concentration under vacuum yield grape Marc extracts with high antioxidant performance.

Keywords: extracts, grape pomace, antioxidant activity, reducing power, phenols, tannins, flavonoids.

\section{References}

1. Kustova I.A., Makarova N.V., Kalendareva E.V. Kachestvo i ekologicheskaia bezopasnost' pishchevykh produktov III mezhdunarodnaia nauchnaia konferentsiia s elementami nauchnoi shkoly dlia molodezhi. [Quality and ecological safety of food products III international scientific conference with elements of a scientific school for youth]. 2015, pp. 44 48. (in Russ.).

2. Karre L., Lopez K., Getty Kelly J.K. Meat Sci., 2013, vol. 94, no. 2, pp. 220-227.

3. Özvural E.B., Vural H. Meat Sci., 2011, vol. 88, no. 1, pp. 179-183.

4. Kulkarni S., DeSantos F.A., Kattamuri S., Rossi S.J., Brewer M.S. Meat Sci., 2011, vol. 88, no. 1, pp. $139-144$.

5. Choi Y.-S., Choi J.-H., Han D.-J., Kim H.-Y, Lee M.-A., Kim H.-W., Lee J.-W., Chung H.-J., Kim C.-J. Meat Sci., 2010, vol. 84, no. 1, pp. 212-218.

6. Rababah T., Hettiarachchy N.S., Eswaranandam S., Meullenet J.F., Davis B. J. Food Sci., 2005, vol. 70, no. 3, pp. S228-S235.

7. Jungmin L., Chrictopher R. Food Chem., 2011, vol. 126, no. 1, pp. 295-300.

8. Rockenbach I.I., Rodrigues E., Gonzaga L.V., Caliari V., Genovese M.I., Schmidt G., Fett R. Food Chem., 2011, vol. 127, no. 1, pp. 174-179.

9. Skerget M., Kotnik P., Hadolin M., Hras A.R., Simonic M. Knez Z. Food Chem., 2005, vol. 89, no. 1, pp. $191-198$.

10. Crespy A. Rev. fr. oenol., 2002, vol. 30, no. 195, pp. 23-27.

11. Obradovic D., Oatey M., Schulz M. Austral. and N.Z. Grapegrow. and Winemaker, 2005, no. 98, pp. 51-53.

12. Rufino M.S.M., Fernandes F.A.N., Alves R.E., de Brito E.S. Food Chem., 2009, vol. 114, no. 4, pp. 693-695.

13. Mariken J.T.J., Sebastiaan Dallinga J., Hans-Peter V., Guido R.M.M., Aalt B. Food Chem., 2004, vol. 88, no. 4, pp. 567-570.

14. Nilsson J., Stegmark R., Akesson B. Food Chem., 2004, vol. 86, no. 3, pp. 501-507.

15. Qing L., Huiyuan Y. Food Chem., 2007, vol. 102, no. 3, pp. 732-737.

16. Brett C.T., Waldron E.K. Physiology and biochemistry of plant cell wall. Eds. Black M., Cahapman E.J. London: Unwin Hyman, 1990. 194 p.

17. Abdulin I.F., Turova E.N., Budnikov G.K. Zavodskaia laboratoriia. Diagnostika materialov, 2001, vol. 167, no. 6, pp. 3-13. (in Russ.).

18. Ju Zhi Y., Howard Luke R. J. Food Sci., 2005, vol. 70, no. 4, pp. 270-276.

19. Garcia-Marino M., Rivas-Gonzalo Julian C., Ibanez E., Garcia-Moreno C. Anal. chim. acta., 2005, vol. 563, no. 1-2, pp. 44-50.

20. Floris T., Filippino G., Scrugli S., Pinna M. B., Argiolas A., Murru M., Reverchon E. J. Supercrit. Fluids., 2010, vol. 54, no. 2, pp. 165-170.

21. Spigno G., Tramelli L., De Faveri D.M. J. Food Eng., 2007, vol. 81, N4, pp. 200-208.

22. Gapenko Iu.V., Zaiko G.M., Ageeva N.M., Markovskii M.G. Izvestiia vuzov. Pishchevye tekhnologii, 2004, no. 2-3, pp. 39-40. (in Russ.).

23. Khanal Ramesh C., Howard Luke R., Prior Ronald L. J. Agr. and Food Chem., 2009, vol. 57, no. 19, pp. 8839-8843.

24. Tagirova P.R., Kas'ianov D.G. Izvestiia vuzov. Pishchevye tekhnologii, 2010, no. 2-3, pp. 60-62. (in Russ.).

\footnotetext{
* Corresponding author.
} 